University for Business and Technology in Kosovo

UBT Knowledge Center

UBT International Conference

2013 UBT International Conference

Nov 1st, 3:30 PM - 3:45 PM

\title{
The Natural Light In Alvar Aalto's Buildings
}

Parashqevi Tashi

Polytechnic University of Tirana, parashqevi.tashi@fau.edu.al

Ani (Panariti) Tola

Polytechnic University of Tirana, ani.panariti@fau.edu.al

Follow this and additional works at: https://knowledgecenter.ubt-uni.net/conference

Part of the Architecture Commons

\section{Recommended Citation}

Tashi, Parashqevi and Tola, Ani (Panariti), "The Natural Light In Alvar Aalto's Buildings" (2013). UBT International Conference. 6.

https://knowledgecenter.ubt-uni.net/conference/2013/all-events/6

This Event is brought to you for free and open access by the Publication and Journals at UBT Knowledge Center. It has been accepted for inclusion in UBT International Conference by an authorized administrator of UBT Knowledge Center. For more information, please contact knowledge.center@ubt-uni.net. 


\title{
The Natural Light In Alvar Aalto's Buildings
}

\author{
Parashqevi Tashi ${ }^{1}$, Ani Tola(PANARITI) ${ }^{2}$ \\ 1,2 Polytechnic University of Tirana, Department of Architecture, \\ Faculty of Architecture and Urban Planning \\ Str."Muhamet Gjollesha” Nd.54 Tirana, Albania \\ e-mail: parashqevi.tashi@fau.edu.al \\ e-mail:ani.panariti@fau.edu.al
}

\begin{abstract}
This study analyzes the design and implementation of various forms of architectural elements, the use of panels, materials, color resolution up to technicaldetails that Alvar Aalto used for the natural light and illumination of interior spaces in buildings designed by him. First some of the most important buildings designed by Alvar Aalto were analyzed. Furthermore the types and forms of windows for natural lighting were demostrated in graphic ways, showing the efficient use of natural light in different seasons of the year and different positions of the sun. The aim of the research is to identify the details and methods used in natural light in the illumination of the interior spaces of different objects as libraries, museums, etc.. This study is important because it gives important conclusions of the architectural form importance, its various elements and the use of natural light efficiently lighting interior spaces in buildings.
\end{abstract}

Keywords: Natural light into the building, Alvar Aalto, Natural light, Modern architecture.

\section{Introduction}

\subsection{Alvar Aalto's life (1898-1976)}

Alvaro was born in Kourtane in 1898. His father was a surveyor, and his survey maps and outdoor fieldwork affected Alvar's understanding of terrain and the location of buildings in outdoors. In 1916 Aalto enrolled in the University of Technology, Helsinki, where he began to study architecture. In 1923 moved back to his home town, Jyväskylä, where he opened an architectural practice. In 1924 he married Aino Marsio, also an architect, but in 1949 she died and Aalvaro remarried in 1952.His new wife, Elissa Mäkiniemi, also participated closely in her husband's design work. The change in location marked the start of the architect's functionalist period. He moved towards a rational architectural language, inspired by Le Corbusier's ideas. Aalto was in contact with the international avant-garde of both architecture and art. He made a major contribution not just to modern architecture, but also as a designer of furniture and art glassor applied art. The architect received various awards, among the RIBA Royal Gold Medal for Architecture, the AIA Gold Medal and the Medaille d'OR of the Academie d'Architecture in Paris. He builded a new separate studio elsewhere in Munkiniemi, where his archives are still located today.

\subsection{Alvar Aalto's works}

During his entire career Aalto designed over 500 individual buildings, 300 of which were build, the majority of which are in Finland, but he has a few buildings in the USA, Germany, Italy and France. Alvaro's paintings were not made as individual artworks but as part of his process of architectural design.

Alvar Aalto's architecture was considered to be highly unic and personal in its nature. Aalto had never wanted to take part in discussions about its works because he thought that the object speaks itself. When studyind Aalto's architecture, we observe that his architectural elements, forms were, independent of chronological development throughout his work. Some of these elements include light, space fragmentation. The undulating surface is another element that has appeared in Aalto's work as ceiling, 
wall, building form, space, glass vase, door handle, wood sculpture and furniture. In Aalto's works, most important it is the variety of scales at which the undulating surface is incorporated.

Natural lighting in the building is realized with the use of conical pyramidal skylights, and horizontal glazing. fan shape clerestory.

\section{Case study:}

North Jutland Art Museum"Kunsten" in Aalborg / Denmark, The Mount Angel Abbey Library, Oregon, Baker House Massachusetts U.S.A, Viipuri Library (Vyborg Russia), Main Building of the University of Technology.

\subsection{North Jutland Art Museum "Kunsten" in Aalborg / Denmark (1958-1972)}

The museum is a major work in the history of Danish architecture in being the only building in Denmark by the world-renowned Modernist architect Alvar Aalto and the Danish architect Jean-Jacques Baruël.

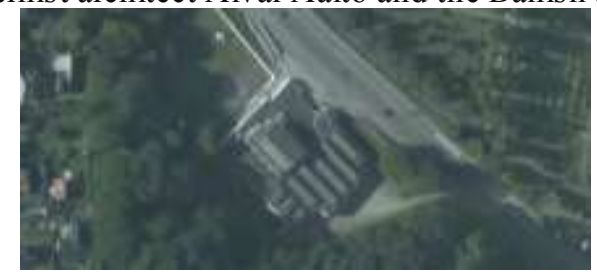

Fig. 1. Satellite image

Notes: geographical location of the building $56^{\circ} 02^{\prime} \mathrm{N} \quad 9^{\circ} 54^{\prime} \mathrm{E}$

The museum is designed to blend in with its natural surroundings, Situated on the edge of a large area of parks and woodland the North Jutland Art Museum, is a very flexible building, that, due to the mobile partition wall system, can change character, depending on the requirements of each individual exhibition .The clean lines of the marble clad building volumes, and the green copper roofs, blend harmoniously with the natural surroundings. The museum is famous for its beautiful natural light transmitted down onto the works of art via parabola-shaped skylight constructions.

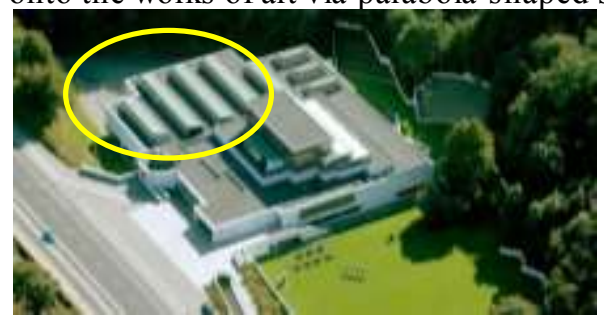

Fig. 2. Aereal view

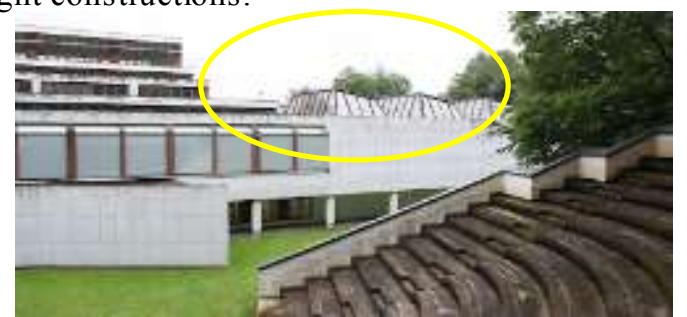

Fig. 3. Elongated sky lights of the building

The total area is approx.6000sq.m.With its roof rising in steps around the central hall, the building resembles a pyramid with a skylight in its lantern-like crown. The hall is flanked on two sides by a lobby and on the other by exhibition rooms, which can be divided flexibly by means of moveable wall units. Aalto here made use of a special lighting system consisting of two -sided, elongated skylights which on the south side prevent the sunlight from penetrating at an angle up to $56^{\circ}$ (corresponding to Aalborg's latitude), but is open up to $90^{\circ}$ on the north side.
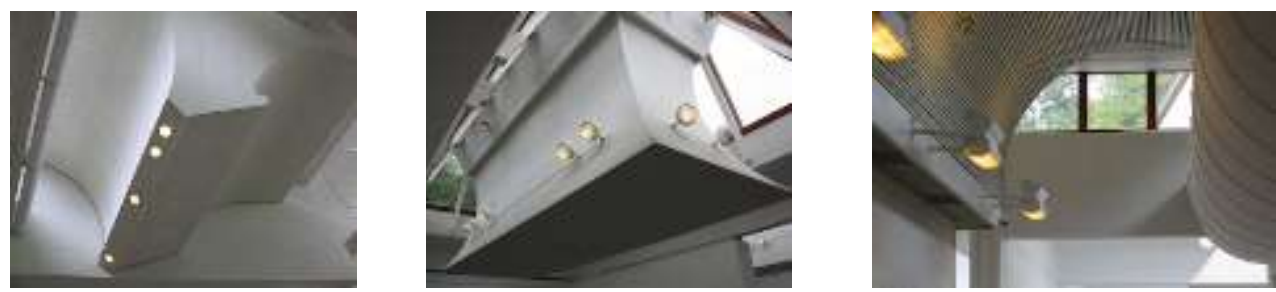
Fig. 4, 5, 6. Parabolic reflecting surfaces

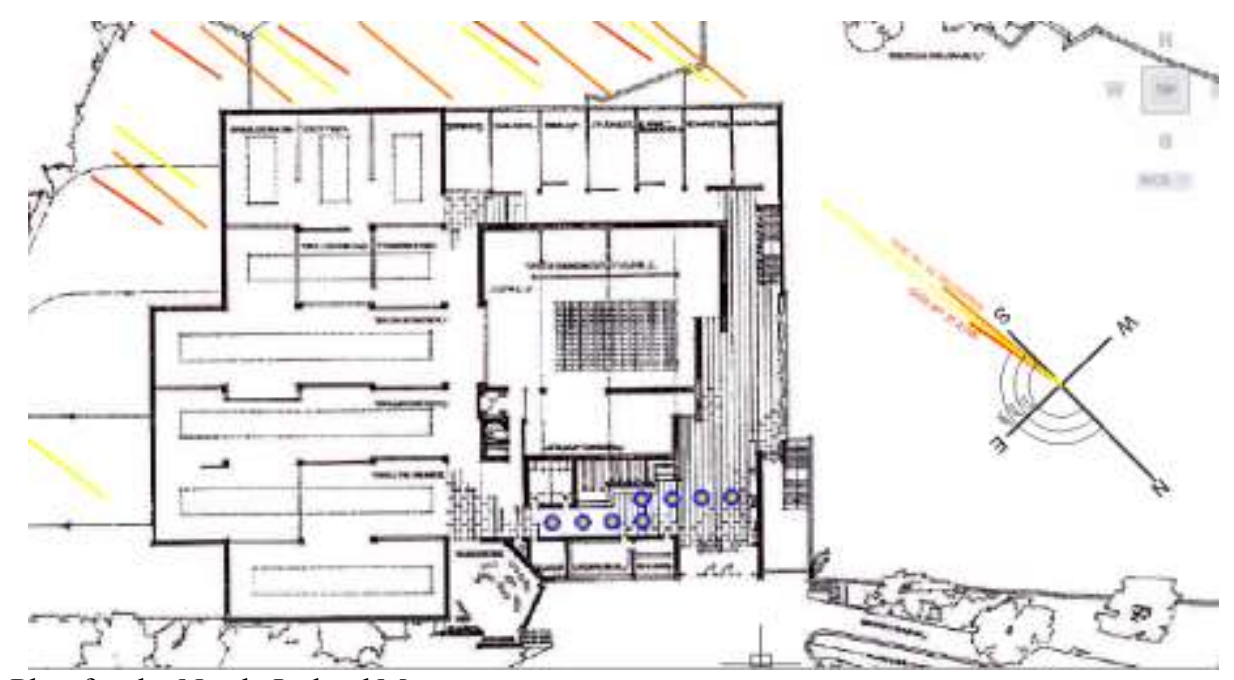

Fig. 7. Plan for the North Jutland Mus eum

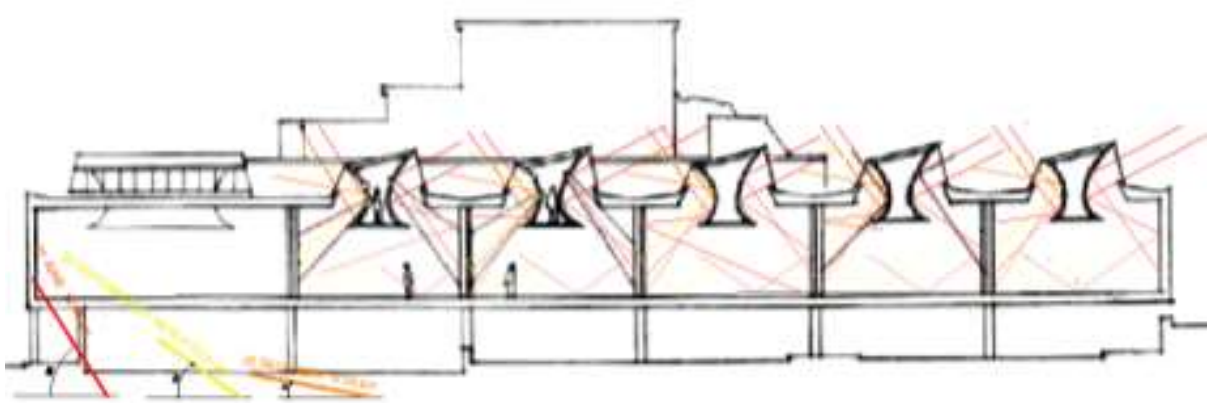

Fig. 8. Section of the North Jutland Museum

Notes: Sunlight angle of refraction and angle of reflection

Figure 8 represents the effect of using double parabolic reflecting surfaces. They are suspended from the ceiling, reflecting the light onto the walls shadowlessly. The main storey has a music room the natural lighting of which is realized with the use pyramidal s kylights, and horizontal glazing. Sunlight angle in figure 2 is the result of the: Analysys of direct sunlight on 4 seasons.

summer solstice 21 june 2012 at 12:00 $\mathrm{h}$

altitude $\quad 56^{\circ} 1^{\prime} \quad$ sunrise at $03: 26 \mathrm{~h}$

asimuth $169^{\circ} 5^{\prime}$ sunset at 21:21h length of day 17.9 hours

winter solstice 22 december 2012 at 12:00 h

altitude $\quad 9^{\circ} 4^{\prime} \quad$ sunrise at $08: 59 \mathrm{~h}$

asimuth $174^{\circ} 6^{\prime}$ sunset at $15: 42 \mathrm{~h}$ length of day 6.7 hours

spring equinox 21 march 2012 at 12:00 $\mathrm{h}$

altitude $\quad 33^{\circ} 2^{\prime} \quad$ sunrise at 06: $20 \mathrm{~h}$

asimuth $171^{\circ} 7^{\prime}$ sunset at $18: 39 \mathrm{~h}$ length of day 12.31 hours

autumn equinox 22 september 2012 at 12:00 $\mathrm{h}$

altitude $\quad 33^{\circ} \quad$ sunrise at $06: 07 \mathrm{~h}$

asimuth $176^{\circ} .8^{\prime} \quad$ sunset at $18: 20 \mathrm{~h}$ length of day 12.2 hours

2.2 The Mount Angel Abbey Library, Saint Benedict, Oregon, USA 1964-1967 
In 1964 Aalto designed a library building in the midst of the older educational and religious buildings in the countryside. The Mount Angel Abbey Library is a building where the pleasure of reading is combined with the efficiency and functionalism of a competent and specialized learning center.

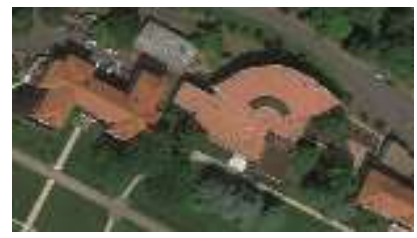

Fig. 9. Satellite image

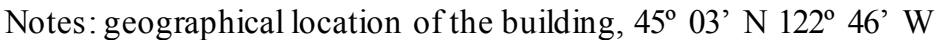

An extensive shelf system configures the structure and the organization of the space. The building contains studio rooms and reading tables distributed on three rooms with good natural lighting.
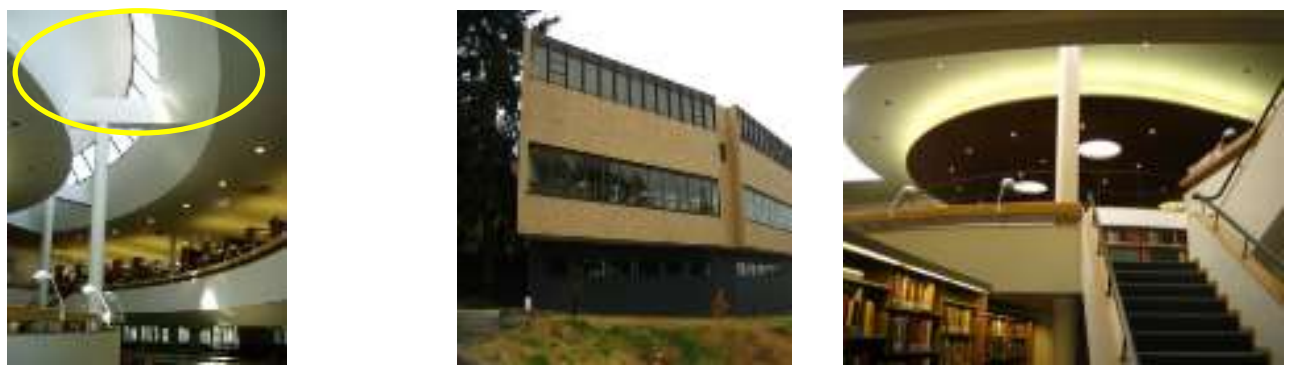

Fig. 10,11, 12. Clerestory skylights and horizontal glazing

Natural lighting in the building is realized with the use of conical skylights, horizontal glazing and fan shape clerestory (Fig.10, 11, 12). A very functional modification is the addition of an artificial light source above the skylight which provides light during the winter days (fig.13). The interior of the Library is organically pleasing. All of the pieces fit beautifully together. It is not just the lighting, but also the shapes, the volumes and the textures which all seem to come together quite nicely. The lending desk at the centre of the fan is surrounded by a curved clerestory skylight which provides shadowless light to the landings on three levels and to the connecting staircas es. All of the lighting, no matter where you sit or stand, is soft. There are few shadows, even at night, when you no longer have the benefit of the soft natural lighting. The central skylight creates an atrium-like space that attracts people. The space is evenly illuminated, with few shadows. Without being outdoors, there is a sense of the weather and time of the day. Indirect sunlight enters the building from the main skylight and bounces off the surrounding ceiling and wall surfaces. The light comes from a multitude of directions.

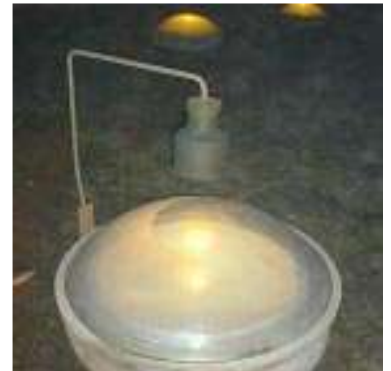

Fig. 13. Artificial light above the Conical skylight
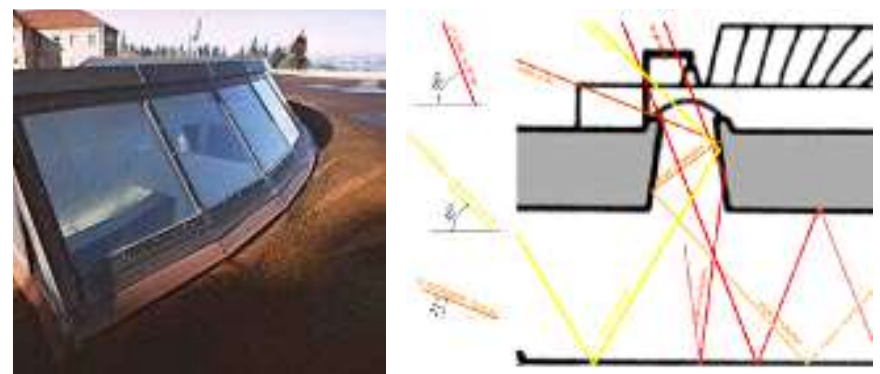

Fig. 14. Clerestory Fig15 Section: light angle of fall, angle skylights

of refraction and angle of reflection 


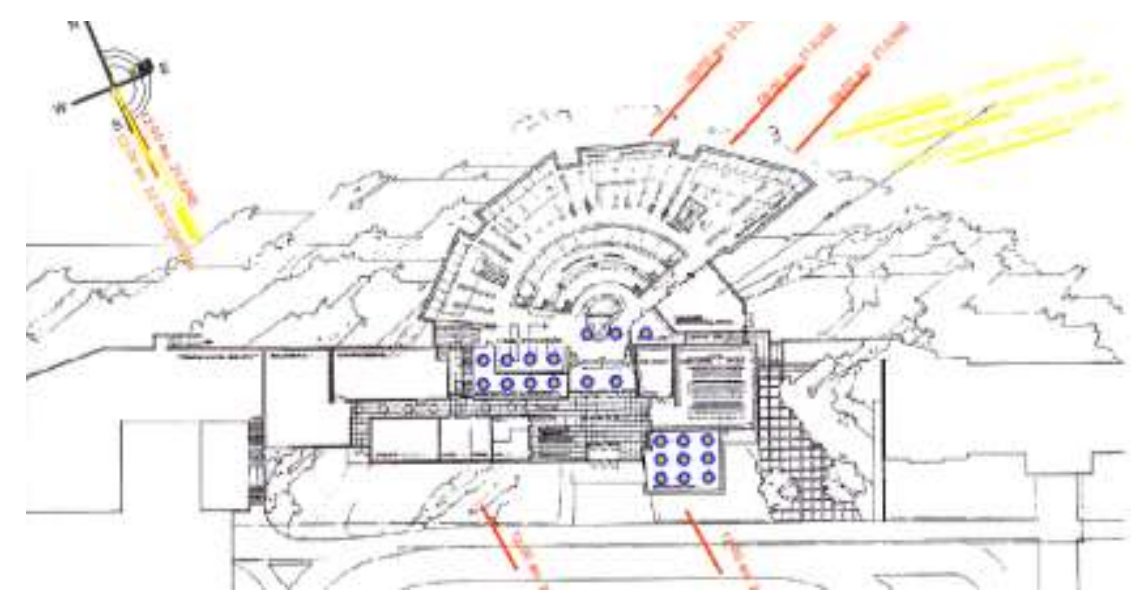

Fig. 16. Plan of Abbey Library

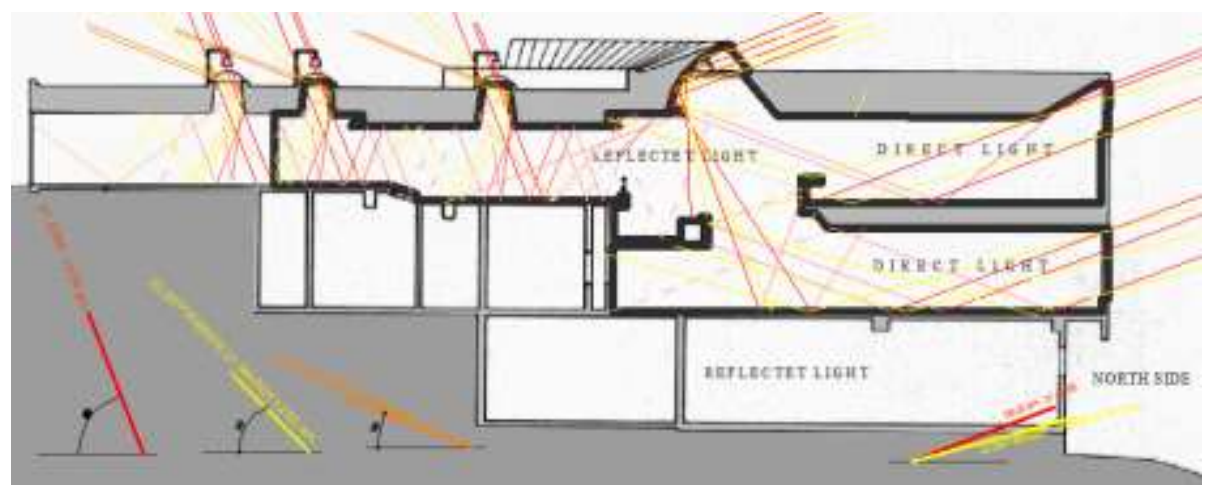

Fig. 17. Section of Abbey Library

Notes: sunlight angle of refraction and angle of reflection.

Figure 17 represents the effect of using conical and clerestory skylight. Alto using clerestory skylights and making a fragmentation to the space creates the opportunity to directly illuminate even the quotes below.

Sunlight angle in figure 17 is the result of the: Analysys of direct sunlight on 4 seasons summer solstice 21 june 2012 at 12:00 h

altitude $\quad 68^{\circ} 3^{\prime} \quad$ sunrise at 04: $23 \mathrm{~h}$

asimuth $173^{\circ} 5^{\prime}$ sunset at $20: 00 \mathrm{~h}$ length of day 15.6 hours

winter solstice 22 december 2012 at 12:00 $\mathrm{h}$

altitude $\quad 21^{\circ} 5^{\prime} \quad$ sunrise at $07: 46 \mathrm{~h}$

asimuth $177^{\circ} 4^{\prime}$ sunset at $16: 32 \mathrm{~h}$ length of day 8.7 hours

spring equinox 21 march 2012 at 12:00 h

altitude $\quad 45^{\circ} 5^{\prime} \quad$ sunrise at $06: 10 \mathrm{~h}$

asimuth $175^{\circ}$ sunset at $18: 25 \mathrm{~h}$ length of day 12.25 hours

autumn equinox 22 september 2012 at 12:00 $\mathrm{h}$

altitude $\quad 44^{\circ} 9^{\prime}$ sunrise at $05: 58 \mathrm{~h}$

asimuth $175^{\circ}$ sunset at $18: 06 \mathrm{~h}$ length of day 12.4 hours

\subsection{Baker House}

Senior Dormitory for MIT, 362 Memorial Drive Cambridge, Massachusetts, USA, 1946. In 1937 the institute gave him the chance to build in a response to the issues of technology, monumentality and 
humanism, to design Baker House, a large dormitory for senior students. The chosen site on Memorial Drive was long and relatively narrow and ran parallel to the adjacent Charles River.

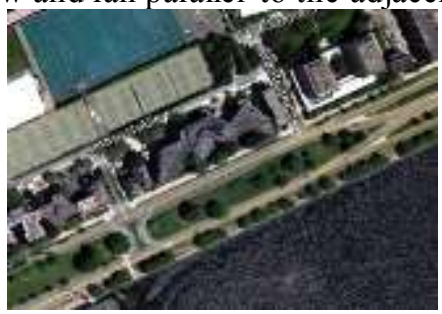

Fig. 18. Satellite image

Notes: geographical location of the building, $42^{\circ} 21^{\prime} \mathrm{N} 71^{\circ} 05^{\prime} \mathrm{W}$

Despite his reputation as an intuitive designer whose ideas emerged from soft-pencil sketches. Aalto presented the project as an exercise in rational design. In a series of comparative studies, he illustrated the advantages and disadvantages of various more conventionally "functional" volumetric arrangements, evaluating each in terms of sun, view and privacy. His point was that while the serpentine, double-curved form he chose might appear "irrational", a formal echo of the meandering river rather than a logical solution to the problem, in fact it made best use of the site by affording nearly every room both sunlight and a view of the river.
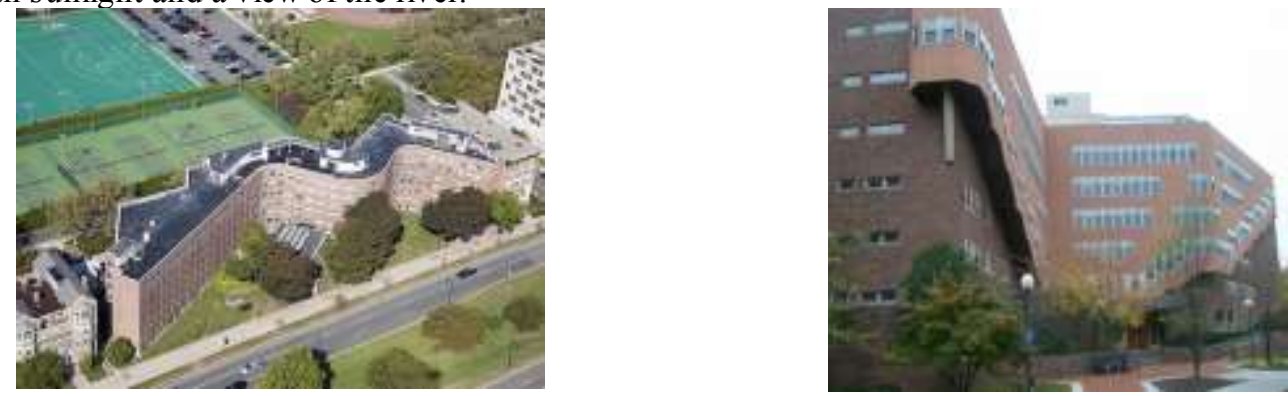

Fig. 19, 20. Aereal view and perspective of the building

The serpentine plan generated a variety of room shapes, which the students soon named "coffins, pies and couches", and was set against an orthogonal, diagonally aligned, two-storey block containing the communal facilities. The building's undulating formalso does not subject the views of the rooms to be oriented at right angles towards the busy street. The main corridor was broad and varied, swelling and narrowing in response to the density of use or to accommodate informal sitting areas. The form established a wide variety of room shapes, creating 43 rooms and 22 different room shapes per floor that although similar, still required distinct designs for the placement of built-in furniture. Aalto refused to design north-facing rooms since he wanted most rooms to have a view of the river from the east or west, and thus proposed enlarging the rooms on the western end into large double and triple rooms that receive both northern and western light.Instead of rooms, a stairway systems (Fig. 21, 22) is housed on the north side of the building with an unobstructed view of its surroundings. Aalto's choice of stairs a cantilevered pair that cascaded, scalaregia-like towards the main entrance - gave the elevation facing the campus a distinctive, and decidedly monumental quality.
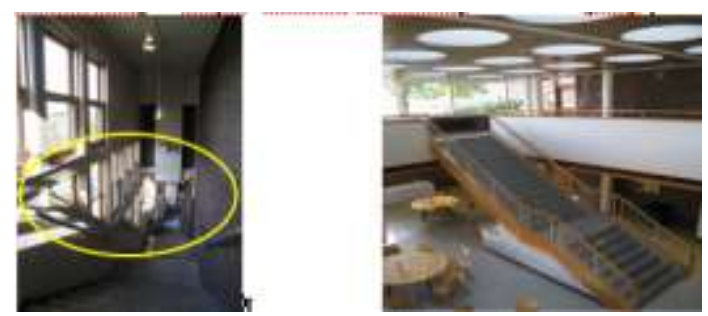

Fig. 21, 22. Image of stairway systems 
Looking across the Charles, the building's silhouette shines in the dawn or dusk. Its hundreds of hardwood, custom-crafted windows bring the building to life as nothing else can. Originally, the pine windows were painted a light gray and required frequent maintenance. Then those windows were all replaced with aluminum in the 1970s. But the cold visual impression of metal could not erase the memory of the original architect's warm use of rich, vibrant wood.

For the brick walls, Aalto chose a rough clinker brick that came in a surprising variety of colors and irregular shapes. He asked that even the most erratically formed ones should be used - some are literally banana shaped and appear to be on the brink of falling out of the walls - and also specified that the bedding joints should be more deeply recessed than the vertical joints. The result is a building that reflects a flexible standardization. In Baker House, Alvar Aalto makes use of pyramidal skylights The skylights open spatially to the sky above and are heated by the lighting fixtures which also provide supplemental winter lighting, while keeping the snow off.

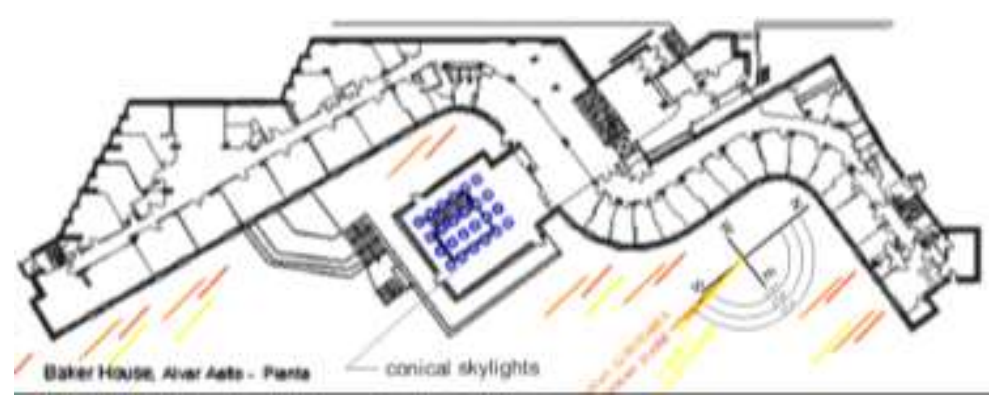

Fig. 23. Plan of Baker House

Figure 23 represents the effect of using conical skylights.

Sunlight angle in figure 23 is the result of the: Analysys of direct sunlight on 4 seasons.

summer solstice 21 june 2012 at 12:00 h

altitude $\quad 70^{\circ} 9^{\prime}$ sunrise at $04: 07 \mathrm{~h}$

asimuth $188^{\circ} 7^{\prime}$ sunset at $19: 25 \mathrm{~h}$ length of day 15.29 hours

winter solstice 22 december 2012 at 12:00 h

altitude $\quad 24^{\circ} 2^{\prime} \quad$ sunrise at $07: 10 \mathrm{~h}$

asimuth $\quad 185^{\circ}$ sunset at $16: 16 \mathrm{~h}$ length of day 9.1 hours

spring equinox 21 march 2012 at 12:00 $\mathrm{h}$

altitude $\quad 48^{\circ} 3^{\prime} \quad$ sunrise at $05: 45 \mathrm{~h}$

asimuth $184^{\circ} 3^{\prime}$ sunset at $17: 58 \mathrm{~h}$ length of day 12.22 hours

autumn equinox 22 september 2012 at 12:00 $\mathrm{h}$

altitude $\quad 47^{\circ} 4^{\prime} \quad$ sunrise at $05: 32 \mathrm{~h}$

asimuth $\quad 189^{\circ} \quad$ sunset at $17: 41 \mathrm{~h}$ length of day 12.15 hours

\subsection{Viipuri Library}

Vyborg, Russia 1933-1835. In 1927, Aalto won the competition for the Viipuri City Library. Aalto drafted the final version and the library was inaugurated on October 14, 1935. The building compromises two elongated volumes that blend to create a common area that uses the entrance, the stairs and the vestibule to the auditorium, as well as some reading rooms and the children's library, which Aalto designed with special attention to the details.

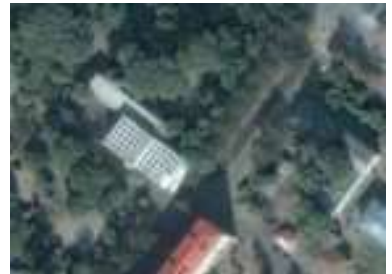

Fig. 24. Satellite image Notes: geographical location of the building, $60^{\circ} 42^{\prime} \mathrm{N} 28^{\circ} 44^{\prime} \mathrm{W}$ 


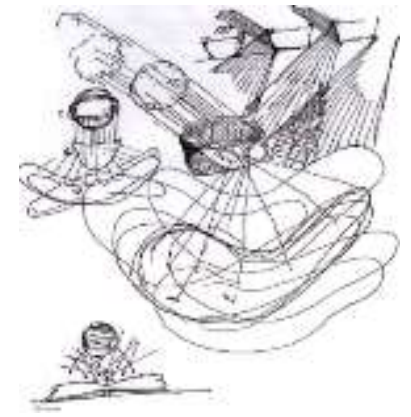

Fig. 25. Sketch of barrel skylights

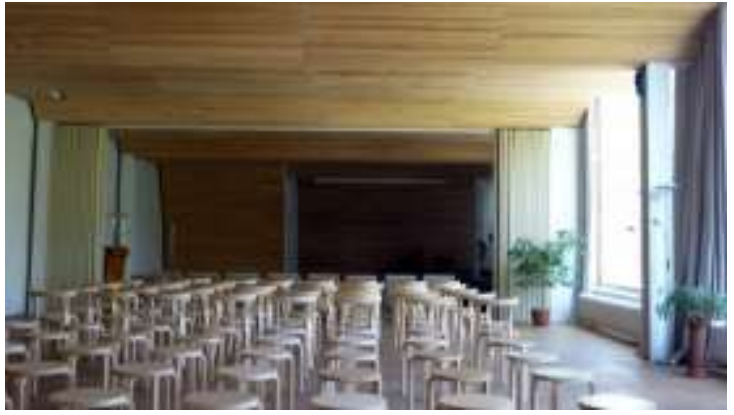

Fig. 26. The Hall's undulating ceiling

Aalto reverted to his original idea of top-lighting for the lending and reading rooms, though this time he solved the problems of winter snow and direct sunlight with rows of round barrel skylights which rise above the roof surface and screen the light against brusque changes of illumination that would disturb readers. Other important innovations included a generous use of light, unpainted wood paneling, irregular serpentine lines in the interiors, and specially designed, functional light fixtures.

In Viipuri Library Aalto integrates the modern esthetic into his handling of volumetric, functional, spatial, and environmental relationships. The library's architectural core consists of reading and lending areas at different levels and plateaus while the centre and control area from the high point above the different levels.

In the ceiling of the meeting hall of the Viipuri Library the undulating surface (Fig.26) became a significant and dominant architectural element. The ceiling's importance lies in both its rational function, as seen fromAalto's statement concerning the flowing quality of the sound as it moves through the space

The diversity of architectural forms Aalto has created to bring light into his spaces, the manner the skylights spatially model the ceiling surfaces. and the manner in which the lighting forms mediate between inside and outside, make Aaltos 's utilization of light is important on several levels. This is a response to the dynamic Finnish environment, with its dark winters and light summers. A majority of the important spaces in Aalto's buildings incorporate the use of skylight and clerestories for obtaining natural light. The ceiling of conical skylights in the Viipuri Library reading area is as significant in Aalto's work as the undulating ceiling of the meeting room.

In the ceiling of the Viipuri Library, (Fig 27) Aalto developed the conical skylights in the reading area. Six feet in depth, they provide a diffused light to the space.

Aalto uses these skylights and also linear ones, to unify, reinforce and articulate the structure. Both skylights not only help define the particulars of the space, but modulate the ceiling to achieve a total synthesis of the ensemble.

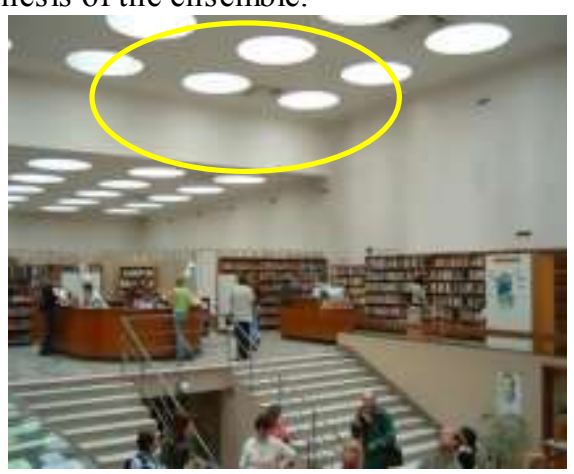

Fig. 27. Interior of conical skylights

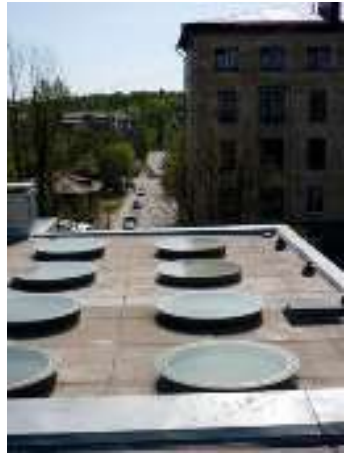

Fig. 28. Exterior of conical skylights 


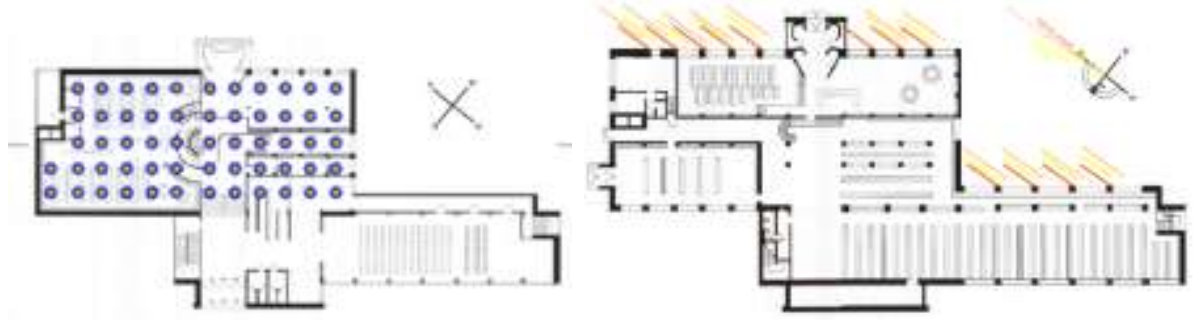

Fig. 29. Plans of Viipuri Library

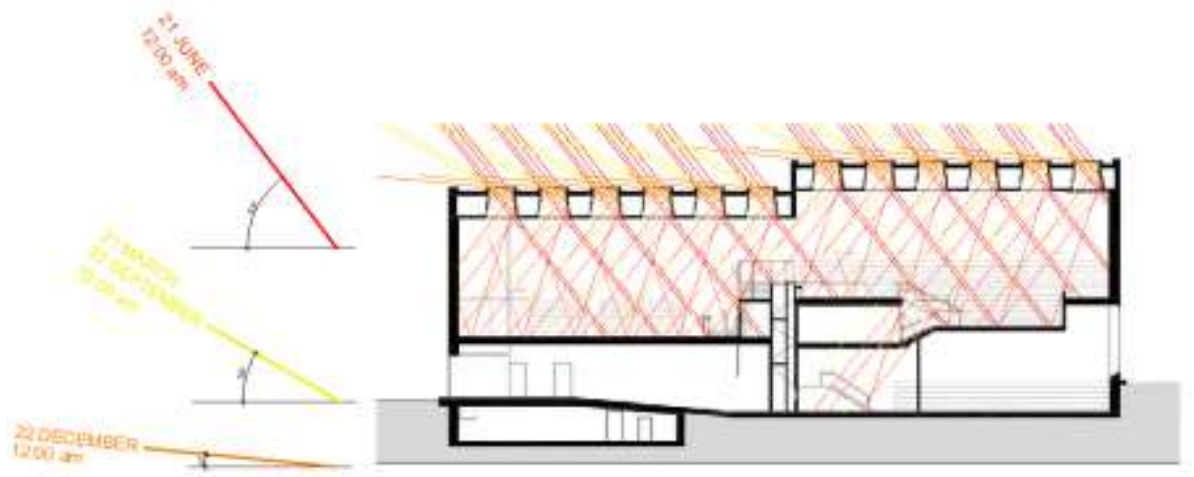

Fig. 30. Section of Viipuri Library

Notes: Sunlight angle of refraction and angle of reflection.

Figure 30 repres ents the effect of using conical skylights and horizontal glazing.

Sunlight angle in figure 30 is the result of the: Analysys of direct sunlight on 4 seasons

summer solstice 21 june 2012 at 12:00 h

altitude $\quad 53^{\circ} \quad$ sunrise at $02: 37 \mathrm{~h}$

asimuth $177^{\circ} 6^{\prime}$ sunset at $21: 39 \mathrm{~h}$ length of day 19 hours

winter solstice 22 december 2012 at 12:00 h

altitude $\quad 06^{\circ} 1^{\prime} \quad$ sunrise at 09: $13 \mathrm{~h}$

asimuth $176^{\circ} 8^{\prime} \quad$ sunset at $14: 57 \mathrm{~h}$ length of day 5.7 hours

spring equinox 21 march 2012 at 12:00 h

altitude $\quad 30^{\circ} \quad$ sunrise at 06: $04 \mathrm{~h}$

asimuth $176^{\circ} 2^{\prime}$ sunset at $18: 24$ h length of day 12.34 hours

autumn equinox 22 september 2012 at 12:00 $\mathrm{h}$

altitude $\quad 29^{\circ} 7^{\prime}$ sunrise at $05: 51 \mathrm{~h}$

asimuth $177^{\circ} \quad$ sunset at $18: 05 \mathrm{~h}$ length of day 12.24 hours

\subsection{Main Building of the University of Technology}

Helsinki University of Technology Otakaari 1 X, Otaniemi, Helsinki, Finland 1953-1967.After Aalto had won the competition for the technical University' new placing in Otaniemi outside the Helsinki city limits in 1949, a long-drawn-out period of development began in 1953, the basic design of the main building being completed in 1955. The building is one of Aalto's most powerfuland convincing designs. Its centre point is the tower-like, beveled cylinder segment that soars from the high point of the site, (Pic.24) where the Otaniemi manor house once stood amid a park now integrated into the university campus. 


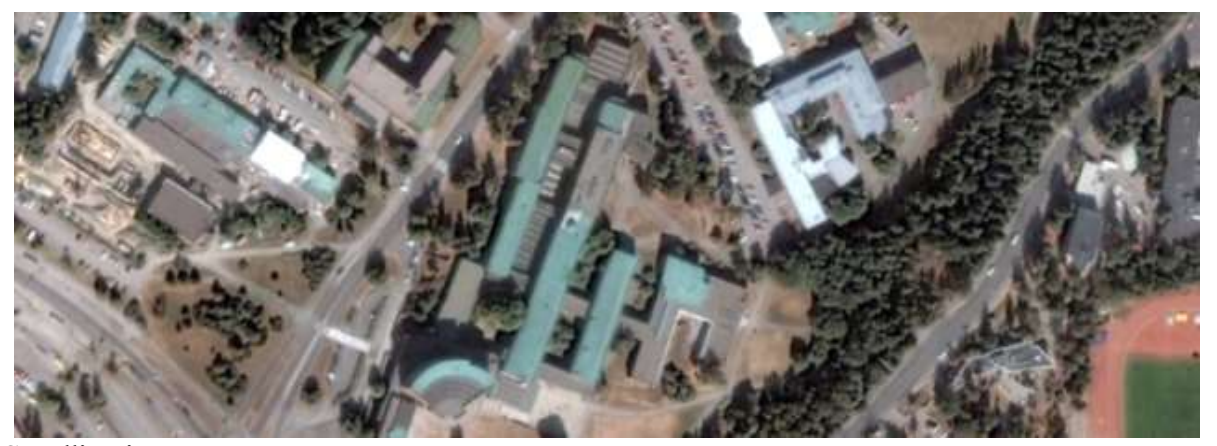

Fig.31. Satellite image

Notes: geographical location of the building, $60^{\circ} 11^{\prime} \mathrm{N} 24^{\circ} 49^{\prime} \mathrm{W}$

The original building program included an as sembly hall seating an audience of 1000 .

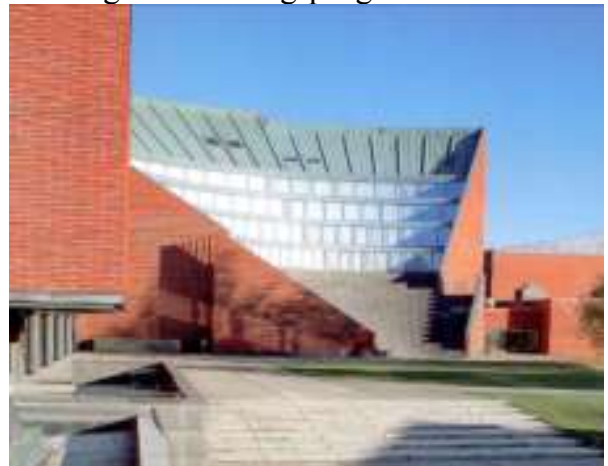

Fig. 24. Image of the building

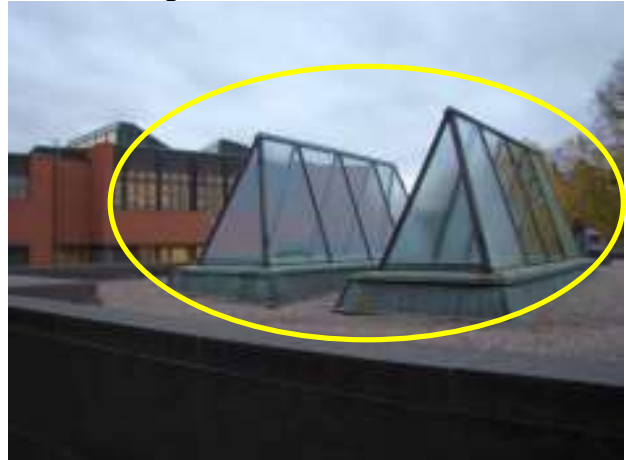

Pic. 25. Image of pyramidal skylights.

Aalto wanted to have a further possibility of building this auditorium by placing in the to wer two auditoria with identical cross sections, one seating 576 listeners and the other 327 , separated by a temporary partition. Basically these form a single cavea, with staggered tiers in the shape of a circle segment rhythmically echoed by the steep rise of the roof, in which vertical "stair" surfaces are replaced by rows of windows. The two large, adjacent auditoria, furnished with acoustic wall elements, project a magnificent sense of space.

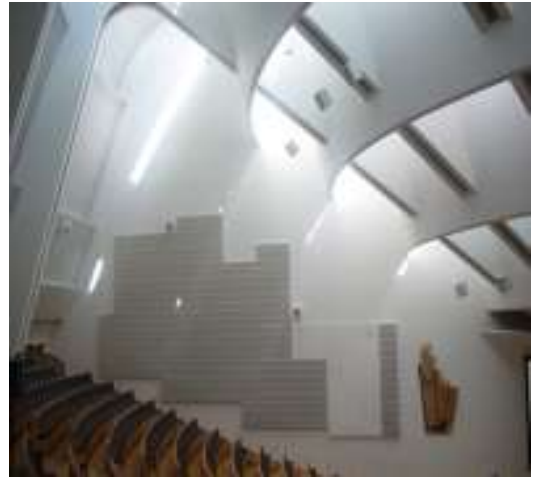

Pic. 26. Interior of the auditorium

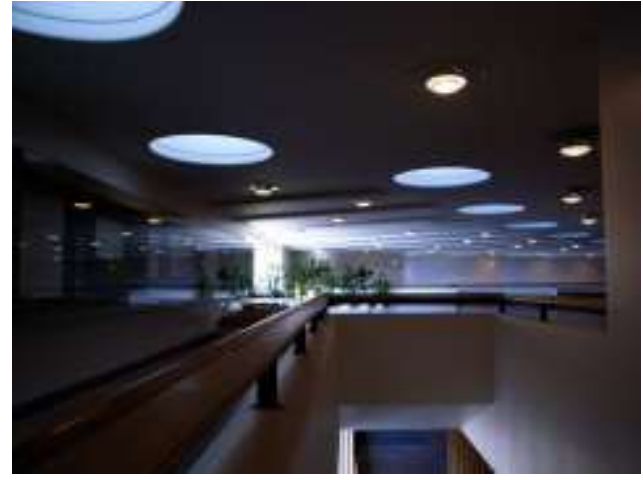

Pic. 27. Interior view of conical skylights 
Around this centre piece, which has an entrance hall at ground level, the other parts of the building complex are grouped irregularly on storeys 1-4 like dominoes which can be linked as needed, forming smaller courtyard patterns. On third floor to one side of the tower is the administrative section with the principal's office, council room, etc; on second floor is a rectangular auditorium and hall space; and on ground floor the teacher's and students cafeterias. On the other side are class rooms for first and secondyear general studies, a physics laboratory lit by oblong prisms in the roof, and auditorium for 310 listeners, and the departments of surveying and architecture. One cannot help suspecting that Aalto favoured these two departments that for biographical reasons were closest to his heart: the other departments, with their laboratories, classrooms, etc, are in separate buildings designed by other architects.

In exterior planning, Aalto-true to his principles-separated motorized traffic on the outside of the complex from pedestrian traffic on the inside, where green lawns and pathways to the other departments and student housing from a peaceful campus. At the beveled lower tip of the tower, Aalto build a small open-air theatre as a termination to the staggered roof, a place for students to gather informally for discussions, sunbathing, or even to listen to the principal's speeches from an adjacent window in the administrative wing. All of the parts of the building are planned to allow extension without damaging the original structure. The main materials used for the building are black granite, specially manufactured dark red bricks, and copper. All of the departments are designed so as to accommodate enlargement without damaging the overall impression. The firs enlargement of the main building took place between 1966 and 1976, consisting of a new two-storey office wing on the south side and new auditoria and other additional space on the west.

Marble has been used for the places which are eventually intended to house a collection of architectural fragments, as especially the collection's historical parts will harmonize best with this material. This collection, which will certainly take time to develop, corresponds in the teaching of architecture to the other department's laboratories, and must therefore be placed on a par with them in budgeting.

Fig. 9. Plan of Main Building of the University of Technology

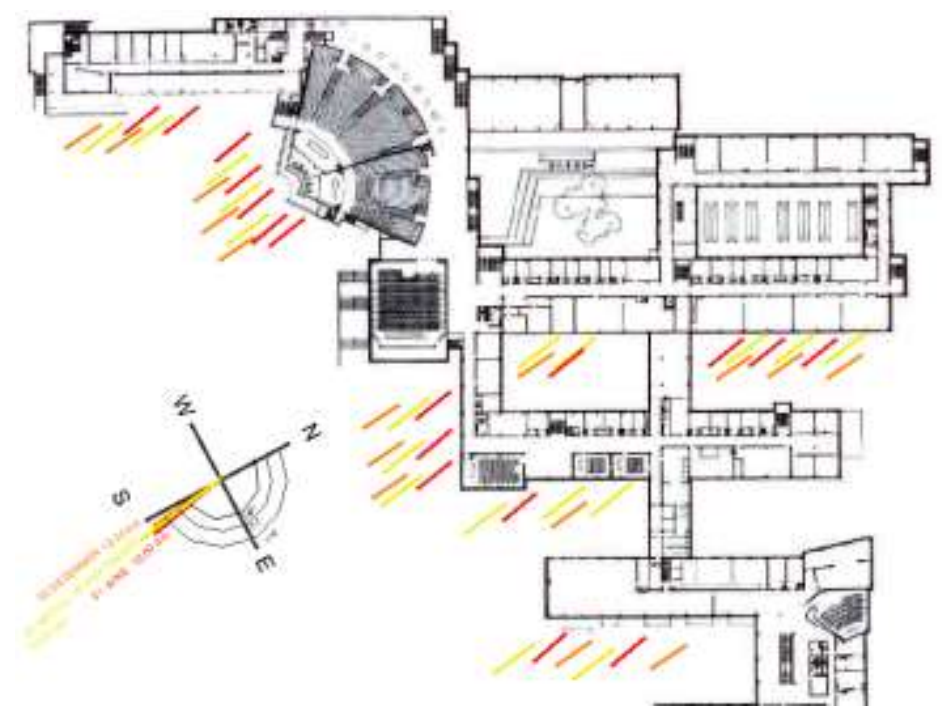




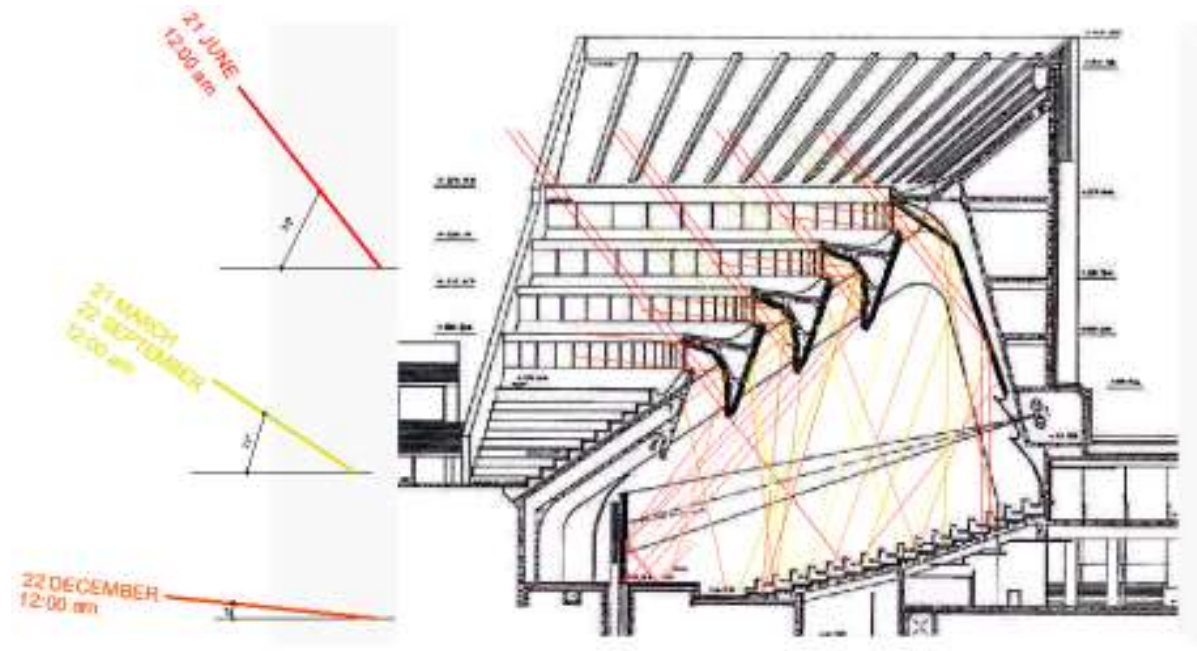

Fig. 10. Section of Main Building

Notes: Sunlight angle of refraction and angle of reflection.

Figure 10 represents the effect of using conical, pyramidal skylights, fan shape clerestory and horizontal glazing.

Sunlight angle in figure 10 is the result of the:Analysys of direct sunlight on 4 seasons.

summer solstice 21 june 2012 at 12:00 $\mathrm{h}$

altitude $\quad 52^{\circ} 1^{\prime} \quad$ sunrise at $02: 56 \mathrm{~h}$

asimuth $171^{\circ} 6^{\prime} \quad$ sunset at $21: 51 \mathrm{~h}$ length of day 18.9 hours

winter solstice 22 december 2012 at 12:00 h

altitude $\quad 06^{\circ} 3^{\prime} \quad$ sunrise at 09: $26 \mathrm{~h}$

asimuth $174^{\circ} 2^{\prime} \quad$ sunset at $15: 16 \mathrm{~h}$ length of day 5.8 hours

spring equinox 21 march 2012 at 12:00 h

altitude $\quad 30^{\circ} 1^{\prime} \quad$ sunrise at $06: 20 \mathrm{~h}$

asimuth $171^{\circ} 6^{\prime}$ sunset at $18: 40 \mathrm{~h}$ length of day 12.34 hours

autumn equinox 22 september 2012 at 12:00 $\mathrm{h}$

altitude $\quad 29^{\circ} 9^{\prime}$ sunrise at $06: 07 \mathrm{~h}$

asimuth $175^{\circ} 8^{\prime} \quad$ sunset at $18: 21 \mathrm{~h}$ length of day 12.24 hours

Notes: Figures of Plans and Section with graphic drawings explainations of the sunlight angle of refraction and angle of reflection are part of personal research.

\section{Conclusions}

Alvar Aalto was a master at utilizing light which is very important to us in this climate and Aalto understood this

Alvar Aalto concerned himself with the problems of light, staircase and handrail, space, texture, the reconciliation of inside and outside, sinuosity, scale, and the passage of time, architectu ral concerns from which he developed an expressive architectural language. Aalto never forgot the role and purpose of the architect. His concerns were architectonic ones explored and examined in the context of designing and building. Alvar Aalto, the architect, believed in architecture as an affirmative act, and that the role of the architect is to design and build. His style was contextual and vernacular, he was very sensitive to contours of the land, angles and direction of the sunlight. He was very conscious of the need for social settings linked directly to natural surroundings with the use of natural landscape. They achieved this through natural living conditions, the use of natural materials, and integration within the boundaries of landscape and vegetation. Nature, sun, trees, and air all served as functions in creating a harmonious balance between natural and artificial.He is one of the most important architects of modern architecture and its influence is growing. 


\section{References}

1. Goran Schildt (1994). Alvar Aalto,The complete catalogue of Architecture Desing and Art.

2. Karl Fleig (1994). Alvar Aalto.

3. Goran Schildt (1984). Alvar Aalto, vol. I The Early Years, Rizzoli. New York.

4. Goran Schildt (1986). Alvar Aalto, vol. II Decisive Years, Rizzoli. New York.

5. Goran Schildt (1991). Alvar Aalto, vol. III The Mature Years, Rizzoli. New York.

6. Fabio Mangone, Maria Luisa Scalvini (1993). Alvar Aalto. Laterza, Bari-Roma.

7. http://www.iie.org/en/Offices/New-York/about-alvar-aalto 